\title{
Pest Problems of Oil Palm and Management Strategies for Sustainability
}

\section{Kalidas $\mathbf{P}^{*}$}

Directorate of Oil Palm Research, Pedavegi, India

\begin{abstract}
Oil palm, Elaeis guineensis Jacq. is an introductory crop to India to mitigate the gap in demand and supply of vegetable oil requirement of the country. Though utmost care is being taken to restrict the entry of any pest population along with the seed sprouts from the importing countries, still many pests are found to infest the crop causing yield losses. Few such pests are rhinoceros beetle, leaf web worm, psychid, slug caterpillar, scales and mealybugs. Except the leaf web worm, Acria sp. rests all are found to migrate from the local ecosystem. Most of these populations are found to migrate from other arecaceae palms like coconut, palmyrah and areca nut which are commonly seen in the adjoining areas of oil palm plantations. The loss estimation on the yields of oil palm due to the above pests was in the range of $20-30 \%$ extending to three years after attack. However, this is further found dependent on the management practices being taken by the farmers with restoration to the normal yield levels within few years of attack. The loss in the yields due to rhinoceros beetle was mainly due to the breaking of leaves at the petiole region where the pest attack is commonly seen. Nearly $25 \%$ yield loss is reported with the $50 \%$ breaking per palm. The pest which is common on coconut and palmyrah found migrating to oil palm due to more number of leaf production. Metarhizium anisopliae is found to act as good biological control agent causing green muscardine disease to all the stages of the pest. Psychid, Metisa plana and slug caterpillar, Darna catenatus which are reported to be minor pests of coconut, palmyrah and maize, found to cause heavy infestation on oil palm causing yield losses upto $50 \%$. The causes of migration may be the existence of congenial conditions like low temperatures and high humidity in the oil palm plantation. The yield losses due to these migrant pests lead to instability on sustainability of the yield as well as cultivation and hence necessary to take good management practices.
\end{abstract}

Keywords: Oil palm; Coconut; Palmyrah; Rhinoceros beetle; Psychid; Leaf web worm

\section{Introduction}

Oil palm is the richest source for vegetable oil production with a capacity of 4-6 tons of oil per ha per year. It is the most sustainable crop to feed the hungry mouths of the world as it is recognized universally as the most efficient, effective and highest yielding form of edible oil production [1]. The eco friendliness is manifested as it is a perennial plantation crop, maintains its green canopy throughout 30 years of its economic life and does not cause soil erosion, river siltation, etc. With the cultivation of oil palm, the farmers can get more returns as the Benefit Cost Ratio for oil palm is more than 1.8 [2] It can replace the other non remunerative crops which are posing threat. It is a labour saving crop as it is not labour intensive like other crops. The cost benefit ratio of oil palm in Malaysia is 3.0 which could be the reason for the fast growth of Malaysia's economy [3].

The vegetable oil consumption in India is only $14.10 \mathrm{~kg}$ per annum per person as against the world's average of 23.60. According to $\mathrm{FAO}$, the minimum quantity required for human consumption is 18 kgs. Only $50 \%$ of our consumption is being produced from the nine oil seeds crops and rest is being imported spending huge amounts of foreign exchequer. To mitigate the gap between demand and supply of vegetable oil in the country, the crop is introduced to cultivate using irrigation [4]. Since 1990 onwards, it is under cultivation in extensive areas in 11 states in India. Andhra Pradesh is leading with 1.02 lakh hectares of oil palm plantation extending in ten districts.

Apart from high productivity, the crop also works as a good sink for carbon dioxide absorption and source for oxygen production. One hectare of oil palm plantation produces an amount of 21.96 tonnes of oxygen per annum while absorbing 30.28 tonnes of $\mathrm{CO}_{2}$. It is far superior over other oil seeds crops whose production and productivity of vegetable oil (less than 1 tonne) as well as oxygen (2.54 tonnes) is far below to oil palm [5].
Though the crop is more sustainable in many ways to growers, processors and to the government, however in the recent years, heavy incidence of pest population is observed causing defoliation and thereby yield loss. This warrants the farmers to go for pesticide application causing environmental pollution and problems to pollinating weevils. Since sustainability of the farmer is the prime concern for cultivation of any crop, at the same time the interest of vegetable oil consumers is also important.

The Roundtable on Sustainable Palm Oil (RSPO) is a sustainability standard that balances environment, economy and social (Small Holdings) structure of families. ISCC is a sustainability plus carbon certification.

\section{Pest Problems on Oil Palm}

Many pests found on oil palms are specific pests of several species of wild palms [6]. They became adapted to Elaeis guineensis Jacq. when these were brought to this country. Some insect pests are polyphagous. There are at least 80 species of arthropods that are potential pests on oil palms. As the plants grow, the plantation becomes a more favorable environment for pests.

When Oil Palm was introduced to India, several new oil palm pests

*Corresponding author: Kalidas P, Directorate of Oil Palm Research, India, E-mail: potinenikalidas@gmail.com

Received November 15, 2012; Accepted November 25, 2012; Published November 27, 2012

Citation: Kalidas P (2012) Pest Problems of Oil Palm and Management Strategies for Sustainability. Agrotechnol S11:001. doi:10.4172/2168-9881.S11-001

Copyright: (c) 2012 Kalidas P. This is an open-access article distributed under the terms of the Creative Commons Attribution License, which permits unrestricted use, distribution, and reproduction in any medium, provided the original author and source are credited. 
of psychidae and limacodidae were appeared in Little Andaman Island. In other areas, oil palm shared some pests with already established crops like coconut, areca nut and palmyrah $[7,8]$. However, damage is varied with the intercrops.

Most harmful insects of Oil Palm are Rhynchophorus palmarum, Alurnus humeralis in America, Oryctes rhinoceros in South East Asia, Oryctes monoceros in West Africa [9]. In India, heavy populations of coccinellidae on the spear region and Rhynchophorus ferrugineus were recorded in Kerala [10]. The great majority of the pests are, however, defoliators. These cause explosive attacks with incidence observed in certain years and areas. Though the reasons are not clear, pest resurgence and secondary pest out break cannot be ruled out [11]

Indiscriminate use of pesticides eliminates all beneficial organisms. Similarly, the uses of herbicides eliminate several species of plants that serve as sites for refuge and feeding for the beneficial organisms. A wide spread attack by a defoliator can cause losses in yield of as much as $50 \%$, at 4-6 months after the attack [12]. Full recovery of an area that was severely defoliated can take several years. An explosive increase of a defoliator does not occur until the leaves of adjacent plants come into contact with each other. This makes it easier for certain insects to move from one plant to another and creates a favorable environment for the pest.

The detrimental effect of defoliation may not be much severe on young plants. In Sumatra and Honduras, reduction of $10-25 \%$ and $22-$ $36 \%$ respectively in yield was recorded due to defoliators [13]. Whereas in Colombia, populations of 4000-5000 larvae of defoliators per leaf, caused losses of foliage of as much as $95 \%$. Losses of $60-66 \%$ of the foliage have caused accumulated reductions in the yield of $36-40 \%$ in the three years. Defoliation of less than $29-38 \%$ has caused losses in yield of $9 \%$. In Sabah, Malaysia reduction of $27 \mathrm{t}$ of FFB occurred during the 30 months following the defoliation of $60 \%$ by Setora nitens [14]. In coastal Andhra Pradesh, defoliation caused by Acria sp. resulted to the yield losses of $29 \%$ in the first year, $31 \%$ in the second year and $21 \%$ in the consequent year [15] (Table 1 and Figure 1.).

Rhinoceros beetle, Oryctes rhinoceros is a serious pest of oil palm in Malaysia [16]. In areas of severe damage, as much as $15 \%$ of the leaf

\begin{tabular}{|l|l|l|l|l|l|l|l|l|l|l|}
\hline Years & $\mathbf{9 7 - 9 8}$ & $\mathbf{9 8 - 9 9}$ & $\mathbf{9 9 - 0 0}$ & $\begin{array}{l}\text { \% } \\
\text { change }\end{array}$ & $\mathbf{0 0 - 0 1}$ & $\begin{array}{l}\text { \% } \\
\text { change }\end{array}$ & $\mathbf{2 0 0 1 - 0 2}$ & $\begin{array}{l}\% \\
\text { change }\end{array}$ & $\begin{array}{l}\mathbf{2 0 0 2} \\
\text { Dec }\end{array}$ & $\begin{array}{l}\% \\
\text { change }\end{array}$ \\
\hline Plot I & 160 & 196 & $22.5+$ & 143 & $27.04-$ & 149 & $4.19+$ & 100 & $32.88-$ \\
\hline Plot II & 153 & 180 & $17.64+$ & 155 & $13.88-$ & 138 & $10.96-$ & 123 & $10.86-$ \\
\hline Plot I & & & & & $27 \%$ & & $24 \%$ & & $49 \%$ & \\
\hline Plot II & & & & & $14 \%$ & & $23 \%$ & & $32 \%$ & \\
\hline Average & & & & $21 \%$ & & $24 \%$ & & $41 \%$ & \\
\hline
\end{tabular}

Table 1: Impact of infestation of leaf eating caterpillars on FFB yield in Indian oil palms.



Figure 1: Effect of leaf eating caterpillar damage on the FFB yield. area can be lost [17], resulting in a yield decline of up to 25\% [18] Damage by the beetles also provides entry points for the red palm, Rhynchophorus ferrugineus and other fungal pathogens that lead to bud rot disease. The pest was reported to set back coconut cultivation in Samoa for 60 years and brings about $60 \%$ decreases in Oil palm yield at the first year of harvesting [19-21].

Psychid (Bagworm), Metisa plana outbreaks are a recurring problem especially in Southern Perak, Peninsular Malaysia. A moderate defoliation (10-13\%) can cause a yield decline of around $30-40 \%$ over 2 years due to decrease in rate of photosynthesis. Mass trapping using pheromones is anticipated to be an easier option for smallholders to adopt. The evaluation of several common designs of sticky traps for trapping male moths and the potential of using them for control purposes has been reported. CpTI plants showed increased tolerance to bagworm larvae (Metisa plana Walker) as compared to non-transformed controls. Integrated Management Practices were developed for the bag worm in Papua New Guinea which include hand collection from young palms, removal of natural host plants from the vicinity of oil palm growing areas, maintenance of good ground cover for beneficials, precise targeting of insecticide by trunk injection and biodiversity management [22].

Reported parasitoids are important in regulating bagworm population [23]. Natural enemies namely Apanteles sp., Xanthopimpla sp., Pediobius sp., and Brachymeria sp., and a non-occluded virus on larvae were reported feeding on bagworms in Malaysia [24]. Their populations are dependent on the availability of shelter and food sources (nectar), provided by beneficial plants in the oil palm ecosystem. Solar radiation that reaches the ground in the young oil palm plantations allows the development of a varied associated flora which leads to high levels of larval parasitism (up to 95\%).

As palms get older, less and less solar radiation reaches the ground and only shade-loving species survive, which do not necessarily support adult forms of most parasitoids.

Four types of plants were considered to be beneficial for bagworm control as they prolong the life span of the adult parasitoids. These include Cassia cobanensis, Crotalaria usaramoensis, Antigonan leptopus and Euphorbia heterophylla [24]. In India, Kalidas reported the increase in psychid incidence in all those gardens that were treated with insecticides against the leaf web worm indicating the secondary pest out break condition. The pest was found causing a loss of $3.88 \%$ photosynthetic area per palm by means of defoliation [25].

\section{Management Strategies}

The following are the problems envisaged in carrying out the management practices in oil palm plantations.

- Height of the plant is the problem for spraying insecticides as they attain more than 20 feet height within 15 years in irrigated plantations.

- Secondary pest out breaks may arise due to indiscriminate use of pesticides that kill the beneficial insects also.

- Pollinating weevils which are important in pollination and bunch production may die and thus cause bunch failures which affect the yield loss.

- Though root feeding and stem injection are being practiced, they are laborious and tedious to carry out. Sometimes, it may pose residue problem. 
Citation: Kalidas P (2012) Pest Problems of Oil Palm and Management Strategies for Sustainability. Agrotechnol S11:001. doi:10.4172/21689881.S11-001

To overcome the above, IPM practices using many alternatives are the sustainable methods to follow. These include:

- Conservation of natural enemies of these pests.

- Creation of congenial conditions for multiplication of natural enemies in the garden.

- Growing pollen and nectariferous plants in the garden like Cassia cobanensis and Antigonon leptopus

- Cultivation of pest tolerant varieties.

- Inundative or inoculative release of bioagents like Trichogramma spp.

- Avoidance of discriminate use of insecticides.

- Collection of the naturally occurring virus, multiplication in large quantity and release against the target pests.

- Maintenance of hygienic conditions in the orchards by removing all the breeding sites of the pests.

- Penetration of the sunlight into the garden by cutting the intermingling leaves and regularly monitoring the pest population.

- High day temperature (maximum temperature) could cause fast evaporation of the pheromone that ultimately affects the longevity of the material.

- Hence, development of stable nanoparticles/nanocapsules/ nanofibres of pheromone will be able to hold the pheromones in sufficiently high concentrations and can control the dissipation rate due to either evaporation or adsorption in an environment.

\section{Conclusion}

The sustainability of oil palm cultivation is the need of the hour for both farmer as well as processor and finally to the country. It is essential to manage the pest population to below economic threshold levels to reduce the losses. For this purpose, integrated management practices need to be developed by using the latest low cost technologies which will give sustainability to the oil palm industry as a whole.

\section{References}

1. Basiron Y (2011) Malaysian Palm Oil-Assuring Sustainable Supply of Oils and Fats into Future. Presentation at the Palm Oil Trade Fair and Seminar (POTS) 2011, South Korea

2. Kalidas P, Sairam CV, Rao KJP (2011) Scientific formula for fixing the price of oil palm (Elaeis guineensis Jacq.) Fresh Fruit Bunches. Journal of Oilseeds Research 28: 143-148.

3. Anon (2011) Presentation on activities of BESOUT 06, FELDA, Malaysia to the visitors from Government of India.

4. Indian Council of Agricultural Research (1988) Potentialities of oil palm cultivation in India. Indian Council of Agricultural Research, New Delhi.

5. Basiron $Y$ (2006) Sustainable Palm Oil Production in Malaysia. In the Symposium on Sustainable Development, London.

6. Wood BJ (1968) Pests of oil palms in Malaysia and their control. Incorporated Society of Planters, Kuala Lumpur, Malaysia.

7. Kalidas P, Rao CV, Nasim Ali, Babu MK (2006) New pest incidence on oil palm seedlings in India-A study of black slug (Laevicaulis alte). Planter 82: 181-186.

8. Kalidas $P$ (2004) Susceptibility of oil palm (Tenera hybrid) planting material for rhinoceros beetle, Oryctes rhinoceros L. Journal of Plantation Crops 32 385-387.

9. Cock MJW, Godfray HCJ, Holloway JD (1987) Slug and nettle caterpillars. The biology, taxonomy and control of the Limacodidae of economic importance on palms in South-east Asia 270.
10. Dhileepan K (1988) Incidence and intensity of rhinoceros beetle infestation in oil palm plantations in India. J Plantn Crops 16: 126-129.

11. Nair MK, Nampoothiri KUK (1992) Oil Palm Production Technology. Central Plantation Crops Research Institute, Research Centre, Kerala.

12. Wood BJ, Corley RHV, Goh KH (1973) Studies on the effect of pest damage on oil palm yield $360-379$

13. Sipayung A, Chenon RD, Sudharto PS (1989) Recent work with viruses in the biological control of leaf eating caterpillars in North Sumatra, Indonesia. Buletin Pusat Penelitian Marihat 9: 14-32.

14. Syed RA, Saleh HA (1998) Integrated pest management of bagworms in oil palm plantations of PTPP London Sumatra Indonesia TBK (with particular reference to Mahasena corbetti Tams) in North Sumatra. Proceedings of the 1998 International Oil Palm Conference, Bali, Indonesia.

15. Kalidas P (2004) Stress management of insect pests on oil palm, Elaeis guineensis Jacq. J Oilseeds Res 21: 220-223.

16. Bedford GO (1980) Biology, ecology and control of palm rhinoceros beetles. Ann Rev Entomol 25: 309-339.

17. Samsudin A, Chew PS, Mohd MM (1993) Oryctes rhinoceros: breeding and damage on oil palms in an oil palm to oil palm replanting situation. The Planter 69: 583-591.

18. Liau SS, Ahmad A (1991) The control of Oryctes rhinoceros by clean clearing and its effect on early yield in palm to palm replants. Proceedings of the 1991 PORIM International Palm Oil Development Conference-Conference (Yusof, B Jalani, B S; Chan, K W; Cheah, S C; Henson, I E; Norman, K; Paranjothy, K; Rajanaidu, N; Mohd Tayeb, D eds.). PORIM, Bangi 396-403.

19. Mariau D (1999) Knowledge of oil palm pests and population management Proceedings of the 1999 PORIM International Palm Oil Congress (Agriculture) Kuala Lumpur, Malaysia 129-138.

20. Dhileepan K (1994) Impact of release of Baculovirus oryctes into a population of Oryctes rhinoceros in an oil palm plantation in India. The Planter 70: 255-

21. Kalidas $P$, Rethinam $P$ (1998) Incidence of leaf web formers on oil palm Programme and Abstracts, National Seminar on Oil Palm Research and Development in $21^{\text {st }}$ Century.

22. Charles $\mathrm{DH}$ (2008) Integrated management practices for oil palm bag worms in Papua, New Guinea.

23. Basri MW, Norman K, Hamdan AB (1995) Natural enemies of the bagworm, Metisa plana Walker (Lepidoptera: Psychidae) and their impact on hos population regulation. Crop Protection 14: 637-645.

24. Sankaran T, Syed RA (1972) The natural enemies of bagworms on oil palms in Sabah, East Malaysia. Pacific Insects 14: 57-71.

25. Anon (2012) Annual Report for the year 2011-12. DOPR, ICAR, Pedavegi. 